\title{
A narrativa jornalística da história: o passado como produto para o mercado
}

\author{
Rodrigo Bragio Bonaldo*
}

Eduardo Bueno, jornalista e editor gaúcho, ganhou fama nacional no final dos anos 1990. Nessa época, aproveitando a proximidade da efeméride dos 500 anos do descobrimento do Brasil, lançou os volumes iniciais a coleção Terra Brasilis. ${ }^{1} \mathrm{O}$ impacto do seu sucesso, com os quatro primeiros livros vendendo em torno de um milhão de cópias, foi recebido com polêmica entre os historiadores profissionais. Seus trejeitos caricatos, suas frases bombásticas, seu linguajar coloquial e, sobretudo, sua ironia, com certeza contribuíram para alimentar as restrições dos acadêmicos em relação aos seus escritos, que, curiosamente, em pouco lembram a personalidade histriônica de seu criador. "Acredite no que escrevo, não no que falo", é uma frase que gosta de repetir. Desconsiderar o aviso e ouvi-lo, no entanto, talvez possa ser bastante revelador.

Esta entrevista foi realizada em março de 2010. Ela é resultado de uma série de encontros. Neles Bueno falou sobre sua carreira de jornalista, lembrou seus tempos como editor, tentou explicar o mercado do livro - sempre provocando e intimando os historiadores a se inserirem nele. Ao longo das horas de gravação, revelou detalhes do processo produtivo de seus textos, desde o papel dos consultores técnicos até as recomendações do editor.

* Doutorando em História pela Universidade Federal do Rio Grande do Sul (UFRGS). Bolsista da Capes.

1 A coleção Terra Brasilis possui até o momento em que escrevo quatro livros publicados: A viagem do descobrimento: a verdadeira história da expedição de Cabral (1998), Náufragos, traficantes e degredados: as primeiras expedições ao Brasil (1998), Capitães do Brasil: a saga dos primeiros colonizadores (1999) e A coroa a cruz e a espada: lei, ordem e corrupção no Brasil Colônia (2006). 
Também deixou claro, com o mar e a mata em mente, o que o inspirava a escrever sobre história, mochila às costas, mesmo que mais tarde os editores ignorassem seus diálogos com os mortos e podassem suas intuições sobre o passado. Eduardo Bueno atualmente dirige sua própria casa editorial, que escreve livros de história sob encomenda institucional. Ele prepara-se para voltar ao mercado e retomar a coleção Terra Brasilis.

Rodrigo Bragio Bonaldo - Você sempre se declarou um jornalista que escreve sobre história. $\mathrm{O}$ que o difere de um historiador?

Eduardo Bueno - Se digo que sou jornalista é por um apreço às ferramentas que a minha profissão me deu e que apliquei plenamente ao exercício desses livros sobre história. Raramente apliquei as ferramentas que penso ser propriamente aquelas do historiador, embora esteja bem consciente que isso tenha se modificado e que o historiador esteja - infelizmente, por um lado - longe de ser o rato de arquivo, o sujeito partindo numa busca incessante, incansável, virtual, pelo documento, pela fonte originária, pela descoberta de novos registros os quais se supõe que existam. Em minha opinião o historiador propriamente dito é quem se empenha na busca de fontes primárias e se possível de documentos inéditos, quase inéditos ou esquecidos. Eu jamais fiz isso. E justamente por não fazer isso, mas acima de tudo por olhar para a história colonial do Brasil com um olhar eminentemente jornalístico, com um propósito jornalístico, com um texto jornalístico que eu resolvi dizer, enfim, que era muito mais um jornalista do que um historiador. Em alguns momentos, é verdade, estive consciente de que isso evitaria alguns confrontos, os quais chamo "corporativistas", com a classe dos historiadores. Não que eu não estivesse disposto a certos conflitos com a classe dos historiadores - aliás, estava e continuo estando - tanto é que quando se criou uma polêmica com aquele programa do Fantástico fiquei felicíssimo, e o Bial e eu dávamos entrevistas e as pessoas perguntavam “e aí, o programa está agradando?" e a gente respondia "sim, ele está agradando", tivemos pico de audiência no Fantástico em praticamente todos os seus oito episódios,- então a gente acrescentava "sim, ele está agradando, mas o melhor de tudo é que também está desagradando”. E estava desagradando a quem? Facções mumificadas da classe acadêmica! Há historiadores que tenho todo o interesse em provocar, porque imagino que fazem parte de uma facção que afastou e ainda afasta as pessoas da história. E eu acredito que este país só pode ser transformado através do conhecimento; 
e o conhecimento histórico sobre a trajetória brasileira é chave para você interpretar a realidade de hoje. Mas sinto que esses senhores nos privaram de abordagens históricas que poderíamos fazer cotidianamente - isso se muitos deles não tivessem transformado a história nessa chatice que eles transformaram. Acima de tudo, eu sempre me senti como jornalista. A minha formação é de jornalista. $\mathrm{O}$ meu olhar é de jornalista. Eu planejei esses livros com um olhar de jornalista no texto e com um olhar de editor no livro como produto. Porque esses livros são um produto. Eu acredito no mercado. Acredito numa economia de mercado. Acredito no poder da venda e do dinheiro e fiz esses livros para vender, na melhor acepção da palavra vender. Do mesmo modo que um cantor que grava um single pensa ter uma mensagem a dar, como eu achei que tinha, lança seu produto no mercado e quer obter sucesso. Ele quer ser escutado. Eu queria ser lido. Então lancei um produto.

RBB - A sua obra de certa forma abriu caminho para um surto editorial de jornalistas que escrevem sobre história. Antes dela, a maioria dos livros do gênero eram biografias históricas como as do Jorge Caldeira ou do Fernando Morais. Como autor, você se reconhece na obra de outros jornalistas-historiadores, que não são biógrafos, como por exemplo o Laurentino Gomes?

EB - Como gênero, certamente. Embora eu ache que ele [Laurentino Gomes] tenha tentado uma coisa um pouquinho diferente dos dois que eu vou citar. Falemos sobre uma das várias coisas que me abriram os olhos para como esse nicho existia, para como havia - e agora vou usar um termo maravilho - uma "demanda reprimida" para textos de história com olhar jornalístico. Várias coisas me abriram os olhos, mas não há dúvida de que duas delas foram os livros do Fernando Morais e as obras do Jorge Caldeira. Mas existem algumas diferenças fundamentais entre o que eu faço e o que eles fizeram. A principal delas é o período histórico. Eles pegaram coisas de um Brasil imediatamente reconhecível, quase de um Brasil contemporâneo. Porque embora o Mauá seja um personagem típico do século XIX - a cara do Segundo Reinado, ou do que o Segundo Reinado deveria ter sido - e a Olga seja um personagem de um Brasil varguista - embora ainda presente em muitos aspectos da superestrutura do país - eles são claramente reconhecíveis como "arautos da contemporaneidade". Especialmente o Mauá, mas também de certa forma o Prestes e a Olga. Acima de tudo aqueles não eram personagens estigmatizados pelos manuais escolares. Eles não estavam no imaginário 
das pessoas, não eram remetidos diretamente ao banco escolar. Minha proposta era trabalhar com o século XVI. Eu sempre particularmente fui muito mais interessado no século XVI; ele é meu século favorito, um século que penso - claro que de forma conscientemente romântica - ser mais luxuriante, com suas matas virgens, com mais frescor, personagens aventurescos, piratas, quase capa e espada. Estou consciente de que essa é uma visão romantizada, mas ela me insuflava, me soprava para esse frescor. Sempre vi a história do Brasil colonial se desenrolando num cenário virginal. Um cenário que eu próprio frequentava naquelas praias desertas de Santa Catarina que tanto me influenciaram no que resolvi escrever. Então havia todo um universo novo que poderia ter esse sopro de frescor - que era o Brasil colonial - e havia, o que me servia, todo um universo caquético, esclerosado, desse Brasil Colônia aprisionado nos manuais de escola. Pero Vaz de Caminha, Cabral... Eram nomes instantaneamente reconhecíveis. Capitanias hereditárias? Pelo amor de Deus - Afasta de mim esse cálice! Pensei: é nesse período histórico que eu tenho que soprar um frescor narrativo, um frescor de olhar. Não era uma proposta de investigar esses acontecimentos com um novo olhar historiográfico. Longe disso, nem teria condições de fazê-lo e, se tivesse, não o faria, porque talvez não vendesse tanto. E como quero dizer desde o início - e é isso que penso que os historiadores deveriam ouvir, dentre outras coisas, se possível, na minha voz - é que existe um mercado pra isso. Existe um produto que tu podes fazer a partir disso e é um produto que vai se revelar mais ou menos rentável e que além de vender e movimentar uma máquina editorial de mercado ainda vai movimentar a academia. Ao mesmo tempo em que vai acrescentar para as pessoas, para o público geral, conhecimento. Esse foi o caminho que eu segui. E esse caminho foi tão extraordinariamente bem sucedido que, sim, gerou toda uma leva de outros jornalistas escrevendo sobre história, dos quais evidentemente o mais bem sucedido é o Laurentino Gomes, com o 1808 , provando que eu tinha aberto um nicho de mercado que estava "escancarado" e que ninguém via. Acima de tudo gerou uma explosão de revistas de história que, se não foram todas que surgiram a partir do sucesso da minha obra, com certeza as duas primeiras foram - confirmadamente, pelos seus próprios criadores - inventadas a partir do sucesso dos meus livros. O Pedro Correa do Lago, então presidente da Fundação Biblioteca Nacional, lançou a revista e declarou na Folha de S. Paulo que havia resolvido criá-la a partir do horizonte que o sucesso dos livros de Eduardo Bueno abriu. Penso que Jorge Caldeira é o principal dos jornalistas-historiadores. Ele é de longe o melhor, 
em muitos aspectos bem melhor do que eu, embora a minha obra tenha tido um alcance popular maior que a dele, mas o significado e o lastro que ele deixou é enorme. Ele criou e dirigiu a editora Mameluco. Lançou a coleção Formadores do Brasil. Pegou um personagem que é uma figura-chave da história nacional, o Mauá, e trouxe-o para as luzes de volta. Por que nenhum historiador fez isso?

RBB - Por que o subtítulo de A viagem do descobrimento: a verdadeira história da expedição de Cabral mudou para um outro olhar sobre a expedição de Cabral? Por que esse primeiro volume tem menos notas de rodapé do que os demais?

EB - Ah, claro que mudou. Afinal, essa foi a única coisa que eu não fiz: o título. Como já disse, a coleção era um produto fechado para o mercado: sete volumes, com formato específico, papel específico, diagramação específica feita pela Ana Adams, com aquelas notinhas laterais, espécie de hipertexto que foge da mesmice da nota de rodapé. E por que o primeiro livro não tem tantas notas de rodapé? Porque o editor não queria a citação de fontes diretas, aquele numerozinho embaixo dizendo "apud alguma coisa", "Vainfas 2009, sei lá o que” - ele não queria isso. Fui proibido. Ele achou que esse procedimento afastaria o público a que ele se dirigia. Acho que estava certo. Embora pessoalmente tivesse gostado de fazer diferente; até para evitar insinuações e alguns problemas que tive. Várias vezes que eu não citei coisas eu não o fiz para evitar interromper o fluxo de leitura do leitor. Ou achas que eu tentei esconder que aquela abertura de $A$ coroa, a cruz e a espada era tirada do Edison Carneiro? Um autor que eu venero! Era quase uma homenagem a ele. Evidentemente tirada dele. Tanto é que, quando fiz aquela abertura de Náufragos, traficantes e degredados eu nem queria citar o Max Justo Guedes ali, porque dá um rompimento. E quanto ao editor, o Roberto Feith? Ele é um sujeito de formação jornalística que nem eu, um dos mais famosos do Brasil nos anos 70 e 80, criador do Globo Repórter, mentor do Lucas Mendes e da carreira do Pedro Bial, esse sujeito, que foi a primeira voz inteligente na televisão brasileira, que te fazia ligar o aparelho e pensar "olha ali alguém dizendo na TV alguma coisa que significa algo! O que raios ele está fazendo na TV?" Ele era feio, totalmente fora do padrão, cabeludo, narigudo - tipo eu - aparecia na TV e tu dizias "esse aí não está de acordo com o padrão Globo de jornalismo". E, no entanto, ele estava ali. Por quê? Porque ele tinha 
algo a dizer. Era um jornalista no melhor sentido da palavra. Completamente determinado a revelar suas fontes - quando isso é necessário - e não fazer nada que não tenha comprovação. Esse sujeito leu todos os livros da coleção Terra Brasilis fazendo sua exegese. Dizia "de onde é que veio isso?", "qual é a fonte para aquilo?", "por que tu estás escrevendo assim?", "de onde tu estás intuindo aquilo outro?". Foi ele quem sugeriu o tal "pode-se supor quê". Ele dizia, "vem cá, isso é uma suposição, não é"? e eu respondia "é óbvio que sim, mas é uma suposição evidente!”. Evidente porque eu mergulhei nesses personagens, me entreguei a eles. Depois, tive a sorte e a benção de conhecer o Joaquim Romero Magalhães, que, dentre outros historiadores, soube compreender a dupla dimensão do meu trabalho: sua grandeza pop e sua "pequenez" historiográfica. Fui elogiado dessa maneira pelo Eric Hobsbawm, pelo Leslie Bethle, pelo Keneth Maxwell, pelo Nicolau Sevchenko e pelo Joaquim Romero Magalhães. Para mim basta. Voltemos ao Roberto Feith. O Feith é quem disse "não tem que ter nota de pé de página" "A bibliografia tem que ser uma bibliografia comentada, ao final do livro", remetendo o leitor à fonte. Se ele quiser saber, ele que vá atrás da fonte. "Porque o nosso tipo de leitor não vai querer o número da página da fonte que tu tiraste". É óbvio que algumas pessoas vão querer saber qual é a bibliografia e é óbvio que eu exigiria pôr a bibliografia - altruisticamente até, no sentido de remeter o leitor às fontes porque uma das coisas que eu mais gostaria na vida é que todos os brasileiros tivessem lido o livro A cidade do Salvador, 1549, do Edison Carneiro. E tu achas que eu teria algum problema deles perceberem o quanto desse livro está presente em $A$ coroa, a cruz e a espada? De forma nenhuma! É que eles não iam ler o Edison Carneiro; eles iam ler o Eduardo Bueno. Eles não iam, muito menos, ler o Teodoro Sampaio, que é outro livro ao qual eu devo todos aqueles detalhes de Salvador. Mas é óbvio que eu também percorri todas as ruas da primeira capital do Brasil depois de ler o Edison Carneiro e o Teodoro Sampaio à exaustão. Eu via tudo! Fui à praia de Naufragados, em 1977, 1980 novamente. Acampei lá. Eu via todos aqueles personagens, aqueles náufragos, piratas, traficantes e degredados, Gonçalves da Costa, Melquior Ramires. E generosamente quis compartilhar a experiência que tive com essas figuras. Compartilhá-la com um universo muito maior. Qual o historiador que fez isso? Em minha opinião, sou o altruísta e eles são os egoístas. Então, esse sujeito que não quis que tivesse pé de página foi o mesmo que me cobrou cada detalhe. E ele me fez - e em muitos aspectos, agradeço - tirar várias induções, várias ilações. Ele dizia "isso aqui não, até acho que foi assim, 
mas não" "Vai nos incomodar", falava. E era essa coisa de ir aos lugares que me levava às induções. Pois então, o livro original era um produto. Eu fiz toda a coleção. Capa, contracapa, orelha, tudo. Escrevi o livro em 44 dias, que, por uma incrível coincidência, é o mesmo número de dias que a viagem do Cabral durou. Escrevi também o release para a imprensa. Entreguei tudo pronto. Chamei o livro simplesmente de "O descobrimento do Brasil". Só que quando chegou na editora eles disseram que tinha que ter um subtítulo. Aí o Feith que é jornalista ligou para mim e disse "'O descobrimento do Brasil'? Que é isso? É piada?”. Eu respondi dizendo que ele que inventasse um nome melhor, se não gostou. Ele desligou. Cinco minutos depois ligou de novo dizendo "que tal 'A viagem do descobrimento'?", e era perfeito, por causa da viagem do Kerouac, eu sou um viajante - viajandão - então eu disse OK. Mas a subeditora dele inventou que deveria ter um subtítulo, e propôs um. Não é que o subtítulo dela foi o mais desastroso possível? "A verdadeira história da expedição de Cabral.” Em primeiro lugar eu não acredito na verdade como absoluta, segundo, se existisse essa verdade histórica, certamente o portador dela não seria eu. Ainda mais sobre uma verdade do século XVI. E aí quando eu tive a chance de reeditar o livro eu disse, pelo amor de Deus, "um outro olhar sobre a expedição de Cabral". O subtítulo anterior me causou alguns problemas, saiu uma resenha em Portugal, um historiador me detonou na revista Oceanos - em parte por causa dele. E aí o livro foi para a gráfica com esse subtítulo. Mas quando teve uma reedição eu mudei para "um outro olhar", no conceito proustiano de que um outro olhar talvez já estivesse mais do que na hora de aparecer e estivesse, ironicamente, mais próximo de uma noção mais abstrata e profunda de verdade.

RBB - Qual o papel efetivo dos consultores técnicos da coleção? O Ronaldo Vainfas e a Sheila Faria, como eles trabalhavam?

EB - Mais o Ronaldo Vainfas. Com a Sheila Faria não tive nenhum contato. Quanto a isso, mais uma vez vem o mérito do Roberto Feith. Ele chegou para mim e disse "concordo em fazer essa coleção com uma condição, a de que tenha um historiador que a avalie, que dê o seu aval". Era tudo o que eu queria. As minhas intenções eram as melhores. Por isso me sinto muito tranquilo. Porque é óbvio que meus livros têm defeitos, falhas, mas nenhuma é de má fé, de aproveitamento - são todas em função da minha incapacidade. Nunca tentei ludibriar ninguém. Na verdade acho que são livros generosos, 
altruístas, nesse sentido de entrega, "olha, tá aqui o que eu pesquisei, quero facilitar a vida de vocês e estou dando de mão beijada”. Por quê? Por causa do seguinte: o leitor é o meu freguês. $\mathrm{O}$ meu cliente. Sabe aquela expressão repugnante, "encantar o cliente"? É esse o meu propósito! Muito dos historiadores acadêmicos escrevem para espantar o leitor, como se dissessem "eu sofri tanto para saber tudo isso, e agora tu vais sofrer também, seu filho da mãe". Parece que é isso que eles fazem. "Este é meu conhecimento e se tu quiseres saber o que eu sei, tu vais ter que passar por uma via crucis." O meu propósito é o inverso. Eu digo "olha, eu me esforcei o máximo que podia, li coisas que eventualmente são consideradas chatas, e estou facilitando a tua compreensão delas", embora eu queira que em algum momento fique registrado que não acho nem sequer o Varnhagen, nem muito menos o Capistrano de Abreu, enfadonhos. E eu venero o Teodoro Sampaio! Quando o Feith disse "eu quero que tenha um consultor técnico" o primeiro nome que me ocorreu foi o do Ronaldo Vainfas. Vainfas parecia afeito aos comportamentos desviantes, como a obra dele comprovava. Mas eu resolvi não dizer quem era o meu nome preferido, porque não sabia nada dele, a não ser a obra, e o Feith poderia pensar que eu estava atrás de um profissional que me "protegesse". Aí ele olhou para mim e disse "Ronaldo Vainfas". Então eu vi que tudo se encaminhava para o sucesso. Os livros foram enviados para ele. Ele fazia observações pontuais. Eu tinha que responder às observações dele. Mas eu estava muito cansado e dava muito trabalho responder por escrito. E dentre meus inúmeros méritos - e eu sou um sujeito cheio de méritos, acima de tudo a modéstia, afinal, minha modéstia é a maior do mundo - foi o de ter gente me controlando. Acreditem no que eu escrevo, nunca no que eu digo! Por isso nunca escrevi como falo, como essa figura caricata e histriônica, porque sempre tive, no fundo, um olhar para o mercado - e também sempre tive gente me controlando. Afinal, anedotas explicadas não fazem ninguém rir. E o Brasil, todo mundo sabe, é o país aonde a gente tem que explicar a ironia. Conheces aquela frase do Rimbaud, "eu sou um outro"? Quem escreve é quase um outro. Mas, retomando, embora eu tenha inúmeras qualidades, o poder de síntese não é uma delas. De modo que era muito difícil responder tudo por escrito para o Vainfas. Resolvi ir para o Rio de Janeiro. No Rio, ele observava e eu argumentava, mudei várias coisas, e sou grato a ele. Mas a palavra final, claro, sempre era minha. Depois tivemos um desentendimento. Posso falar abertamente. Ronaldo Vainfas publicou um livro chamado Dicionário do Brasil Colonial, o qual utiliza informações minhas de 
Capitães do Brasil em alguns verbetes dos donatários, mas não me colocou na bibliografia. Ele achou que eu não era digno suficiente de estar na bibliografia. Naquele dia eu disse para o Feith: o nome dele nunca foi tão lido quanto como consultor dessa coleção. Em troca, o Vainfas ligou para o Feith falando que estava incomodado porque eu tinha dado várias entrevistas dizendo que os historiadores escreviam mal e que muito do sucesso da minha obra se devia ao fato dos acadêmicos serem péssimos escritores e eu escrever bem. O que é um absurdo. Talvez alguém tenha publicado assim porque tu sabes que o jornalismo é fugidio e incompetente. Por meses eu gostei de estar do outro lado do balcão! Mas foi nesse momento que lembrei quanta gente já devo ter prejudicado fazendo as sacanagens que o jornalismo faz. Eu fiz muitas delas como jornalista. Fiz muita coisa errada. E daí, de repente, eu me via do outro lado do balcão, com eles publicando um monte de bobagens sobre mim. E o mais grave é que publicaram coisas na minha boca que eu não disse. Repórteres que não gravam, que escrevem "Eduardo Bueno disse que", e eu disse nada daquilo. Realmente disse que havia historiadores que escreviam mal. Mas existem historiadores que escrevem maravilhosamente bem. Quer que eu cite alguns? Ronaldo Vainfas, Lilia Schwartz, Alberto Costa e Silva, Nicolau Sevcenko, José Murilo de Carvalho. Tem um monte! A produção historiográfica brasileira é de primeira ordem. O problema são os livros didáticos - esses é que são os ruins, e não são feitos por historiadores. Agora, tem muita coisa acadêmica ruim. E eu só falei isso. Eu sou considerado um moderninho, por causa dos beats, por causa do Bob Dylan, mas na verdade eu sou - como disse uma vez minha ex-mulher - um homem atrás do meu tempo. Sou zero moderninho. Olha as coisas que eu gosto! O Dylan é um velho! Os beats estão todos velhos! Eu gosto dos velhos. Gosto do Teodoro Sampaio. Gosto do Capistrano e até do Varnhagen. Claro que ele não escreve bem, mas não me irrita. O que me irrita são os historiadores supostamente de "esquerda" e os historiadores supostamente "analíticos", que em minha opinião não analisam nada. Mas o Vainfas me livrou de boas. Meus livros tinham muitas generalizações e simplificações. Algumas eram propositais. Outras eram equívocos. Por exemplo, eu falei que quando se estabeleceu o governo-geral se encerrou de vez o regime das capitanias. Aquele pano rápido do jornalismo. E o Vainfas disse que não. Que não havia se encerrado. O governo-geral foi instalado no Brasil, mas algumas capitanias continuaram sob a administração dos seus donatários. Isso foi na última frase dos Capitães do Brasil. No turning point para entrar nos governos-gerais. E isso é algo que eu devo ao 
Vainfas e sou grato, dentre outros erros mais específicos que ele corrigiu. ${ }^{2}$ Depois me vem com aquele dicionário do Brasil Colônia, pega trechos inteiros dos meus livros - porque não há nenhum lugar em que se encontre perfis pessoais e "psicológicos" dos donatários como tem nos Capitães do Brasil. Eu compilei todas as informações que existiam para retratar eles. Quem era o Aires da Cunha, quem era o João de Barros, quem era o Duarte Coelho, que sabes que eu venero, quem era o Vasco Fernandes Coutinho, quem era o Pedro Tourinho. Isso tem em algum lugar? Não tem, não tem, não tem! Aí o Vainfas faz um dicionário do Brasil Colônia e é óbvio que ele incluiu como verbetes (e não sei se ele o faria caso a Terra Brasilis não existisse) donatário por donatário. Pega trechos que eu sei que chupou de mim. Eu sou jornalista, eu sei! Conheço essas sacanagens! E não me põe na bibliografia... Liguei para o Feith e disse "esse cara não é mais o consultor". Em suma: os consultores foram importantes. O Vainfas me salvou de várias. Mas, a partir de $A$ coroa, a cruz e a espada, eu não precisava mais deles, assim como não precisava mais do aval de ninguém.

RBB - Próximo ao ano 2000, seus textos foram auxiliados pelo gancho das comemorações. Em 2006, apareceu A coroa, a cruz e a espada trabalhando a temática da corrupção, em meio aos escândalos do mensalão. No seu entender, qual o papel do gancho jornalístico para a escrita dos seus livros? O atraso do quarto livro se explica pela espera por uma melhor oportunidade editorial?

EB - Não, não se explica de forma nenhuma. Mas a pergunta é procedente e faz todo o sentido. A coleção foi bolada tendo como gancho os 500 anos. Gancho no sentido jornalístico da palavra. Eu tinha um projeto de escrever sobre história colonial desde 1985. Porém, por uma série de circunstâncias da minha carreira, especialmente da minha vida, eu sabia que não era o momento. Eu não sabia quando era o momento, eu sabia quando não era o momento. Quando chegou 1997, eu conclui que sim, tinha chegado a hora. E ela estava vinculada à efeméride. Porém, a minha experiência como editor

2 Nota de pé de página: o cara é um mala, o Vainfas. Fumava cigarros em cima de cigarros. Nós sentávamos para discutir o livro por, digamos, uma hora. E nessa uma hora ele fumava 20 cigarros. E eu tinha que ficar sentindo aquele fedor, na minha roupa, na minha cara. [Eduardo Bueno realmente disse "nota de pé de página” antes de começar essa frase. Decidi mantê-la aqui.] 
- cara, tu nem merecias essa entrevista que eu estou te dando - comprovava que lançamentos em cima de efemérides no exato momento em que elas estão ocorrendo é uma roubada. Porque em 1989 se fizeram dezenas de lançamentos sobre os 200 anos da Revolução Francesa. Em 1988, antes disso, se fizeram diversos lançamentos sobre os 100 anos da Abolição. Em 1989 se fizeram também montes de lançamentos sobre a República no Brasil. Como, estupidamente, se farão lançamentos sobre a independência do Brasil em 2022. E o momento não é de se fazer quando da efeméride - é de se fazer antes da efeméride, ser como um "abre alas" daquela coisa. E isso é uma coisa que os historiadores acadêmicos poderiam se ligar, porque eu advogo por uma conexão entre a produção acadêmica de melhor qualidade e o mercado. Esses autores tem que produzir coisas que sirvam também para o mercado. Vai ser bom para o Brasil e vai ser bom para eles. E ao produzir para o mercado eles vão ter que se submeter a determinadas regras da indústria editorial que vão dinamizar determinados tipos de texto. Mas eles não aproveitam a efeméride! E quando o fazem, o fazem em cima do laço. Pior: não pensam dentro da abordagem de transportar o leitor para o passado. O leitor quer estar lá, quer ser testemunha presencial... É óbvio que é mais difícil para o historiador de ofício transformar o seu leitor em testemunha presencial. Mas se ele pudesse ao menos flertar com isso, como a mim é concedido... É por isso que eu nunca quis competir com historiador. É em defesa do historiador. Porque ao usar as ferramentas do jornalismo tenho muito mais chance e oportunidade de transformar o meu leitor em testemunha presencial do que o historiador teria. O historiador teria que se esforçar muito mais do que eu para transportar o seu leitor para a cena do que eu posso me permitir. $\mathrm{O}$ gancho da efeméride foi usado. Agora, o fato de sair em 2006 A coroa, a cruze a espada aconteceu por uma coincidência auspiciosa. Afinal, essa é uma coleção muito auspiciosa, muito bem aventurada, no sentido do mercado. Ela atrasou por causa das circunstâncias que se modificaram de minha vida profissional, como editor. Porque eu pude me tornar autor barra editor. Eu sou um dos únicos autores brasileiros, assim com o Jorge Caldeira, e não há de ter sido coincidência, que, por descobrir o nicho do mercado da história pude fazer a transição e me tornar um autor/editor. Ou seja, ter controle, ter ofinal cut, a edição final. Foi em função dessas alterações que resolvi voltar para o mercado, cumprir o contrato e concluir o quarto volume. E dei sorte dele sair em cima do mensalão. Não foi proposital, embora seja muito revelador. 
RBB - Entre o terceiro e o quarto livros da coleção é possível identificar um turning point na narrativa. Como você explica no início de $A$ coroa, a cruz e a espada, o estabelecimento dos governos-gerais decretaria o fim do que, com certa liberdade, se poderia chamar de "período romântico" do expansionismo português. Ao que parece, a ideia de um período romântico é atribuída a Harold Johnson. Eu não consegui encontrar essa menção na obra dele. Seria essa proposta de periodização uma leitura sua da história do Brasil?

EB - Nunca tive a oportunidade de explicar isso. Mas há um lado dos meus livros nos quais eles são totalmente convencionais na periodização. Já no primeiro livro, começo com o descobrimento, seguindo a cronologia tradicional. Sempre bem convencional, porém com uma ginga diferente, é verdade. Se não, vejamos. O fato de eu ter chamado aquelas três décadas de "décadas perdidas” é representativo. Lembra a década de 80 como sendo a década perdida do Brasil, na qual o país não cresceu, não evoluiu - a época do governo Sarney. Chamei as primeiras décadas do século XVI de "décadas perdidas" porque são menos estudadas mesmo, o que significa que as pessoas abordam elas com menos dinamismo e vigor. Quase ninguém escreve sobre elas. Mas é uma periodização. Depois temos as capitanias hereditárias como marco historiográfico tradicional. Mais tarde temos os governos-gerais. Dediquei um livro para cada um desses marcos. Eu me servi dessa estrutura, que é uma estrutura convencional e que poderia ser outra. Estrutura que não quis desafiar. No máximo cheguei a tentar dinamitá-la por dentro. A passagem do terceiro para o quarto livro com certeza foi um turning point. E isso se deve um pouco a uma visão muito romântica minha da vida e da história, do meu lado beatnik e estradeiro. Quando tu não tens o poder estabelecido, plenamente, enquanto o rei ainda não conseguiu exercer inteiramente o poder sobre o novo território, eu identifico esse período como uma época mais romântica e dada à aventura. Eu sei que não é exatamente assim. Ou que se foi assim poderia haver outra leitura. Mas essa foi a minha leitura.

RBB - Quais lugares descritos na Terra Brasilis você já visitou? Qual o papel que visitar esses lugares teve na escrita de seus livros?

EB - Penso que um dos problemas graves que o Brasil tem de não se entender como nação é uma falta de sense of place, a sensação ou sentido do lugar, relacionado a uma certa topofilia, aos laços afetivos que deveriam existir entre os 
seres humanos com os ambientes que os cercam. $\mathrm{Na}$ verdade o processo que me levou a desenvolver interesse pela história iniciou pelo sentimento de deslocamento que eu sentia, tanto na sociedade, na família, no colégio, na cidade. Cheguei a aviltar a possibilidade, inclusive, de me sentir um outcast por desconhecer a história dos lugares em que vivia. O primeiro lugar no qual eu me senti em casa foram as praias de Santa Catarina. Fiz parte da segunda leva de gaúchos a "descobrir" as praias daquele estado. Praia do Rosa, Ibiraquera, Praia do Silveira, conheci algumas delas quando eram totalmente desertas. Mas para me sentir de fato em casa naqueles lugares eu percebi que precisava saber a história das praias. Por isso meu primeiro flerte com o passado foi através da geologia - a história da formação geológica dos lugares. Eu penso que uma das lacunas enormes que existem na produção científica do Brasil é um livro de geologia que não seja escrito em "geologês". Comecei primeiro, portanto, a estudar a formação geológica das praias de Santa Catarina e fui à UFSC, com 18 anos de idade, fazer um levantamento bibliográfico a respeito do tema. Quando fiquei mais familiarizado com a questão, descobri que o cenário estava vazio... E que na verdade esse cenário vazio não possuía tanto atrativo. Conclui que precisava humanizá-lo, para entender como as pessoas perceberiam aquele lugar, a topofilia dos diferentes habitantes que lá estiveram. Foi aí que me interessei por pesquisar quais foram os povos originais daquele litoral. Então encontrei a questão dos sambaquis, conheci o Arno Kern, flertando pela primeira vez com a arqueologia. Cheguei mesmo a conhecer o padre Arlindo Horn, um dos maiores arqueólogos da história do Brasil e o maior especialista em sambaquis, a quem conheci já na casa dos seus 80 anos, embora, é claro, hoje suas pesquisas já estejam há muito ultrapassadas. Em função dele acabei conhecendo o padre Ignácio Schmitz, um dos mestres do próprio Arno. Toda minha incursão nesse tema deveu-se ao fato de, primeiro, eu ter pesquisado o cenário para, depois, tentar humanizá-lo, introduzindo-lhe personagens como se fosse em um palco - por isso mesmo utilizo propositalmente o termo "cenário", "o cenário estava montado, mas vazio". Então eu necessitava de atores históricos nesse cenário, e preferi colocar os índios, mas por quê? Porque, como um hippie, vivendo da mãe natureza, identifiquei-me completamente com os indígenas. Na verdade eu comecei a pesquisar os índios históricos, ou seja, aqueles que tiveram contato com os brancos, no caso de Santa Catarina, os carijós. Mas logo recuei pouco mais no tempo, pois os carijós não eram autóctones daquela região e sim os tais "homens dos sambaquis". Dos sambaquis voltei novamente para os carijós e 
conclui, no entanto, que ainda faltava um outro elemento dramático. $\mathrm{Na}$ mesma época, minhas mãos encontraram um livro que é chave na minha vida, Bury my heart at wounded knee, "Enterrem meu coração na curva do rio". O Dee Brown, autor, é historiador de formação, da universidade de Austin, no Texas, que - e aí vem uma frase pedra de toque - escreve como um jornalista. Tem um texto totalmente fluente, evidentemente voltado para o mercado. Além de ir aos lugares que me interessam, eu costumo ir atrás das pessoas que me interessam: visitei Austin, no Texas, fui atrás do Dee Brown, sem receios, quando passeava pelos Estados Unidos em uma de minhas viagens estilo Jack Kerouac. Dee Brown disse-me que, como qualquer autor americano publicado para o mercado - porque o livro lá é um produto -, ele passava por uma edição, cujo filtro do editor visava encontrar a maneira do texto atingir o maior número de pessoas. Mesmo os historiadores brasileiros, até os que escrevem mal - embora fique aqui a ressalva de que muitos escrevem bem - têm o desejo, não tão secreto assim, de atingir o maior número de pessoas possível. É estranho que alguns tenham quase vergonha de admitir para si mesmos que escrevem para ser lidos. Mas sim, eles escrevem para ser lidos. Infelizmente, muitos historiadores brasileiros escrevem para serem lidos, sim, mas para serem lidos por seus pares. Embora isso já tenha mudado, foi assim durante muito tempo. Enterrem meu coração é um marco definitivo na minha vida. Naquele livro, naquela época, 1980, eu decidi que algum dia ia escrever sobre história colonial do Brasil. Porque percebi ser óbvio que o confronto entre brancos e indígenas no Brasil tinha sido tão dramático, tão intenso e sanguinolento quanto aquele que ele descrevia, quanto o processo de genocídio das tribos norte-americanas. Só que o Brasil, tão pouco afeito a produzir mitologia sobre si próprio, teve a maior corrida do ouro do mundo e onde está o Jack London que registrou isso? E há pouco aconteceu outra em Serra Pelada, quem registrou? Imagine as bandeiras, o que daria de filmes sobre isso? Os bandeirantes tiveram sua atuação 250 anos antes da corrida para o oeste americana, matando índios, escravizando índios, destruindo missões. O único filme que existe sobre as missões que vale a pena é o de Roland Joffé, $A$ missão, com Robert De Niro e Jeremy Irons. Por que o Brasil não produz essa própria mitologia da sua história? Tiradentes é outro personagem que daria uma figura fantástica, mas, quando aparece, temos aqueles filmes enfadonhos lotados de chavões, da época do "Brasil Grande". E Dom Pedro? Imaginem a quantidade de filmes ou biografias se poderia fazer com 
ele. Quando li aquele livro e falei com o Dee Brown pensei que esse era um território que eu poderia explorar. Eram obsessões minhas, mas sabia que o tema era mercadológico. Essa é a verdadeira gênese da coleção Terra Brasilis. Portanto, ela se dá 18 anos antes dos livros saírem. Em função dessas viagens para os Estados Unidos, de minha experiência hippie, em função de eu por vezes me imaginar como um índio em praias virginais, acabei vinculando-me antes com a cultura $p o p$ americana, com a geração beat, com Bob Dylan, etc. Traduzi On the road em 1982, com o livro saindo em 1984. Acabei entrando na indústria editorial brasileira pelo viés pop e beat, ao indicar esse livro para a Brasiliense - fez muito sucesso, vendeu 122 mil exemplares - abrindo-me as portas de várias editoras. Escolhi a L\&PM, pois na época não queria me mudar de Porto Alegre. Comecei a editar muitos livros da geração beat, como Charles Bukowski, John Fante, etc. Mas também encontrei uma brecha para editar pela L\&PM uma coleção chamada L\&PM História, na qual publiquei Bartolomé de las Casas, "Brevíssima história da relação das Índias Ocidentais", que eu chamei de Paraíso destruído. Muita gente não gostou desse título, mas eu o defendo, pois era para vender mesmo, e não me envergonho disso, pois acaso preferem que as pessoas leiam ou não leiam Bartolomé de las Casas? Depois fiz os Diários da descoberta da América, do Cristovão Colombo, mais tarde as cartas do Américo Vespúcio, Cabeza de Vaca embora esse Paulo Marcum venha se apresentando como "descobridor do Cabeza de Vaca”, algo patético - mesmo eu, que publiquei muito antes, não me considero descobridor de ninguém. Esses livros venderam muito. Marco Polo, que recebeu publicação tanto diferente, entrou na lista dos mais vendidos da Veja. É raríssimo um livro de domínio público entrar nesse tipo de lista. Só entram livros que tem autor conhecido, que possui direitos vigentes. O mercado se protege, nesse sentido é muito interessante, dificultando emplacar um domínio público como mais vendido. Tudo isso foi me provando que havia essa "demanda reprimida” por livros de história, que as pessoas gostam de história, especialmente quando ela é apresentada para elas por um viés que tenha ação e aventura. Tudo mostrava que havia um público para "aventuras na história". Depois aprendi que para haver essas aventuras era preciso existir um frescor do cenário. A ação tinha que se desenrolar num setting, numa locação. Eu que já havia viajado para vários lugares fora do Brasil, conhecia pouco o país. Aí comecei a ir aos lugares nos quais a história tinha se desenrolado, isso depois de ler boa parte dos relatos de viajantes. O que é 
ainda mais interessante: muitos desses lugares, locações históricas, ainda seriam, 500 anos mais tarde, paraísos hippies: praia de Naufragados, Porto Seguro, região de Garopaba, Arembepe (onde o Caramuru naufragou), ilha de Itamaracá. Por ir a esses lugares, anos depois me senti preparado para escrever os livros.

RBB - Essas técnicas "realistas" como a descrição das cenas e paisagens - a autópsia, como chamavam no século XIX - de certa maneira lembra a prosa do jornalismo literário. No seu texto sobre o new journalism, de 1994, em Zero Hora, você cita uma frase do Tom Wolfe - "os bárbaros estão chegando”. Seria os jornalistas agora os novos bárbaros da historiografia?

EB - Penso que sim. Penso que foram. Os jornalistas que escrevem sobre história aprenderam com os historiadores, devem isto aos historiadores, pois eles pegaram o que os historiadores tinham de melhor, e pegaram também (e principalmente) o que eles tinham de pior. Pegaram temas eventualmente similares, ou temas esquecidos, para vestirem isso com uma nova roupagem. E era um roupagem meramente estilística, de texto. Eu penso que Fernando Morais e Jorge Caldeira, para ficar em dois exemplos mais próximos, que considero mais eficientes que o Laurentino Gomes, embora tenham vendido menos do que ele, são muito menos influenciados pelo new journalism do que eu. Eu sou gritantemente influenciado pelo new journalism. Infelizmente muito aquém dos mestres, quem me dera eu tivesse a capacidade de escrever como os quatro principais dali: Truman Capote (embora não se identificasse por completo com o fenômeno), Tom Wolfe, Gore Vidal e Gay Talese. Acabei conhecendo pessoalmente o Tom Wolfe e Gay Talese, entrevistei Norman Mailer por telefone. Naquela velha obsessão por conhecer e procurar as pessoas de quem eu gosto. Li todos os livros desses quatro que caíram em minhas mãos. Eles foram uma influência muito grande em mim.

RBB - O quarto livro da coleção Terra Brasilis é dedicado a explorar as origens da corrupção brasileira no período colonial. Os historiadores utilizados para isso, Edison Carneiro e Teodoro Sampaio, no entanto, quando utilizam a expressão "corrupto" o fazem emulando as fontes, a saber, os escritos do padre Nóbrega. E o teor das menções do jesuíta é, em geral, o de uma condenação moral entendida em um contexto teológico específico. Como você lida com essa "tradução" direta para o presente? 
EB - Padre Nóbrega realmente fala em "corrupção" no sentido moral, como um jesuíta, um típico proselitista. Óbvio que ele se referia à moral, mas várias vezes ele menciona como os funcionários eram insatisfeitos, como só queriam lucrar e ir embora, que a feição deles não estava nesta terra. Depois ele foi um sujeito que se chocou diretamente contra o Sardinha. Embora o contexto daquele conflito seja em torno de Reforma e Contrarreforma, e ele soubesse que o cisma tinha começado por causa da venda de indulgências - e, portanto, houvesse todo um revestimento teológico e um debate moral no confronto dele com o Sardinha - eu penso que fica claro que ele também se mostra irritado com o fato de, além de tudo, o bispo roubar no sentido literal. Mas reconheço que essa seja uma preocupação menor dentro do embate teológico. Quanto ao funcionalismo ele também se preocupa muito mais moralmente, tu tens toda a razão. Nesse ponto é claro que eu puxei para o presente. Claro que eu fiz a "autópsia", mais uma vez, e é claro que tentei trazer para o tempo presente. Claro que eu tentei fazer com que o leitor traçasse um paralelo entre aquela corrupção e a de hoje. Porque é como eu digo: I feel like a man with a mission. Eu me sinto um homem com uma missão. Eu acredito que tenho talento para a escritura, talento verbal e penso ser uma voz positiva no Brasil. Eu tenho três filhas e quero um país melhor. Então eu fiz isso com esse propósito, embora não pense que em nenhum momento tenha sido infiel às fontes. Mas é claro que é uma transposição, uma tradução, como no caso do Teodoro Sampaio, quando ele descreve não apenas as empreitadas, mas também os leilóes da hasta pública, quando ele solta aquela frase: "Quando se abre o envelope não havia nenhuma surpresa." E o "superfaturamento", embora em nenhum momento ele fale nisso, tu percebes como eu me interei dos preços - tem até uma tabela de preços - que retirei de um outro livro que pouco referenciei (embora tenha citado na bibliografia final) chamado Cidades indo-portuguesas, deveria ter sido mais explícito até, pois nesse livro tu percebes que as cidades na Índia custavam muito mais barato que aqui. Para isso usei a conversão do pardau para o cruzado e do cruzado para o real. Então se conclui que aqui foi muito mais caro. Pedro Carvalhais, o trato do cal, como eles iam pagar por isso? Era de graça. Os tijolos, a muralha que ainda caiu, mesmo saindo atrasada e superfaturada. E a revolta e a indignação do primeiro arquiteto do Brasil, que não foi pago, não recebeu salário: todos esses são indícios claros de que cobraram do rei mais do que deviam e entregaram menos e atrasado. É claro que a metáfora ali é Brasília. E claro que a metáfora - e que isso fique registrado - é a Odebrecht, a OAS e a Gautama, que são inclusive baianas. É deles que estou falando também. 
RBB - Como é a experiência de trabalhar com essas histórias institucionais?

EB - A produção acadêmica brasileira de ponta é admirável. Por outro lado, a produção acadêmica brasileira que não sai das teses e dissertações me parece, em geral, lastimável. Ela não está interessada em dialogar com a sociedade não só por falta de apelo mercadológico, mas também por não explorar temas pujantes relegados ao esquecimento. Então quando eu comecei a produção de livros institucionais, acabei fazendo coisas que nunca ninguém tinha feito. O fato de não existir uma história da Caixa Econômica Federal no Brasil é algo que deveria cobrir de vergonha os mestrandos e doutorandos de história. O fato de haver duas e fraquíssimas histórias da Loteria no Brasil é absurdo. Como não há uma história da Loteria Esportiva no Brasil? O fato de que não existia nenhuma história da propaganda de medicamentos no Brasil - eu o fiz, e fui o primeiro - é vergonhoso. Não tinha nenhuma história da higiene no Brasil. Tinha, é claro, mas não uma síntese, fechadinha. Tudo bem que o Câmara Cascudo, que acho um gênio, já praticamente esgotou o tema - dentro de sua época, é verdade - fazendo aquela História da alimentação no Brasil. Mas onde está a nova história da alimentação no Brasil? Onde está a história da soja no Brasil? Onde está a história da lavoura de cana no Brasil? Onde está a história do álcool no Brasil? Dos transportes? Das estradas brasileiras? E um livro maravilhoso sobre os transportes no Rio Grande do Sul é escrito por um jornalista! Onde está a história da erva-mate no Brasil, dos coronéis do mate, escrita para que as pessoas possam ler, que entre no mercado? Peguei um tema que já foi amplamente abordado - a história da indústria no Brasil e, depois, a história da indústria no Rio Grande do Sul. E o que havia antes de mim? Se tu olhares as histórias da indústria no Brasil, ou o livro da história da indústria do Rio Grande do Sul, da Sandra Pesavento, que não é ruim, até é bom, vais rapidamente constatar que são todos livros marxistas! São livros de esquerda nos quais os operários são heróis e os empreendedores são criminosos aproveitadores. Em 2010! Eu tenho fama - que alimentei, é verdade - de que sou de direita. Porque quando você não é de esquerda no Brasil você é de direita. Pelo amor de Deus, um cara com a minha trajetória, cheio de rebeldia, ser de direita? Evidentemente não sou de direita. Nem de esquerda. Nem estou em cima do muro. Meu objetivo inclusive é dinamitar o muro. Aliás eu estava em Berlim o dia que o muro caiu, junto com o Rubem Fonseca e com o Pedro Bial, e ajudei a dar as minhas picaretadas no muro. Embora não sei se isso tenha sido um ato de 
direita ou não. Talvez além das picaretadas que já dei no Brasil quem sabe a minha picaretagem no muro de Berlim também não me configure como um cara de direita. Tive a oportunidade de escrever uma história da indústria no Brasil a convite da CNI que em nenhum momento foi subserviente ao ideário da direita e do neoliberalismo e que mesmo assim foi plenamente aprovada pela CNI. Esse estudo, inclusive, teve um lançamento em que foram todos os maiores industriais brasileiros: o George Gerdau, o próprio Norberto Odebrecht - blerg! -, o Benjamin Steinbruch, o Emílio Gauer, etc. Todos receberam o livro, muitos deles o leram, ao menos aqueles que sabem ler o fizeram, já que não são todos. Escrevi a história da indústria no Rio Grande do Sul fazendo uma louvação eventual, mas propositalmente exagerada, de certos empreendedores que como tal foram gigantes. Dentre eles o A. J. Renner e vários outros. Isso me mostrou que essa história cem por cento ideológica está datada e velha. É claro que qualquer escritura é ideológica, qualquer coisa que você escreva é ideológico, qualquer recorte editorial é ideológico. É uma escolha, ao fazer uma escolha você faz um exercício que também é ideológico. É óbvio que eu sei que meus livros não são neutros. Agora você vai dizer que meus livros são de centro, de esquerda ou de direita? Eu diria que eles são no máximo humanistas, no mínimo ingênuos. Na prática a vertente dos livros institucionais me abriu duas possibilidades: primeiro, consegui fazer uma coisa na qual essa ideologia estava só no substrato, não era explícita, mas estava ali. E segundo: me deu a liberdade de ter o final cut, o controle definitivo sobre o meu produto. Eu estou consciente de que se vocês historiadores tivessem que lidar com os temas que lidei essa produção teria que circular dentro de uma moldura formal e conceitual muito mais apertada que a minha. E teria que ter uma escrita submetida a determinadas normas (as quais eu respeito e penso serem muitas delas corretas) que não permitiriam o grau de arejamento e de liberdade que eu tenho. Então eu não posso comparar a minha obra à de um historiador porque eu estaria sendo injusto com o historiador. Se eu me declarasse historiador, chamasse os acadêmicos para um confronto, esse seria um confronto injusto, porque eu possuo meios muito mais sólidos para alcançar grandes vendagens. Eu sempre estive do lado da história e dos historiadores. Tudo que eu fiz eu devo aos historiadores e, quando os critico, o faço de maneira construtiva e generosa. As pessoas chegavam pra mim, perguntavam se eu era historiador. Eu respondia, sim, claro, com "i" maiúsculo. Uma ótima piada! Certo dia, em Parati, o Eric Hobsbawm veio ter comigo dizendo que a anedota era inteligente, mas que 
eu não poderia mais utilizá-la, pois ia me dar um autógrafo que era mais do que um rito de passagem. For one historian to another. "De um historiador para outro", foi o que ele escreveu. Ou seja, ele deu suas bênçãos para mim como historiador, coisa que não penso e nem busco ser. Mas isso porque ele leu o meu livro, entendeu exatamente o que já comentamos, a grandeza e a pequenez do trabalho que faço. Para mim está tudo resolvido, tudo em paz. Só que sou muito desafiador. Quando surgem personagens enfatuados como o finado Lopes ou mesmo o Moacyr Flores, eu perco meu tempo querendo discutir com eles. Agora, se tiver alguém com disposição para discutir de verdade, então eu discutirei. Mas a crítica no Brasil é patética! Ou as críticas que saíram foram totalmente laudatórias, coisas do tipo "contou histórias que ninguém nunca havia contado”, o que obviamente não é verdade, referindose ao Peabiru, Aleixo Garcia, dos náufragos daquela região. Ou as criticas foram feitas por pessoas que, de cara, já não gostavam de mim. Como aquele escroto e mau-caráter do Diogo Mainardi, um sujeito repleto de recalques, que escreveu aquele livro horroroso Contra o Brasil, e que escreveu que meus livros eram manuais ginasianos. Mais tarde, na revista $C$ ult, um jornalista fez a comparação entre a minha obra e a do Mainardi, perguntando-se do que nós precisávamos mais, se dele ou de mim. Minha mãe, Beatriz Bueno, não teria feito uma coisa me defendendo desse jeito. O sujeito parece que é meu irmão, nem sei quem é ele, liguei três vezes para a revista Cult para agradecer e não consegui falar com ele. Ele arrasou com o Diogo Mainardi na comparação, isso aconteceu antes dele entrar para o Manhattan Connection, que pra mim acabou. Uma das tragédias do Brasil é não ter uma crítica literária competente. Se tivesse, [teria] que ser feita uma análise séria, dada a grandeza do fenômeno editorial que eu represento, numa página inteira de jornal, no Estadão, na Folha e no Jornal do Brasil. Minha obra deveria ter sido analisada, primeiro, por um jornalista, depois, por um historiador e, por último, por um crítico literário. O jornalista possivelmente diria que meu texto é jornalisticamente bom, pega temas clássicos da historiografia e os trata como uma grande reportagem. O historiador provavelmente diria que meu texto tem uma importância de divulgação - embora, comicamente, os que disseram isso o tenham feito como se proferissem uma afronta! Graças a Deus faço livros de divulgação, sim. Óbvio que o historiador diria que meu texto tem diversas fragilidades, cuja maior parte deve ser relevada, tem um frescor narrativo, faz uma mistura estimulante entre autores antigos que ninguém mais lê com coisas atuais, se serve de um, deixa outros de lado, sempre fazendo um jogo a seu 
favor (no melhor sentido), que quando quer pegar um historiador antigo o reescreve, e quando quer utilizar um novo o referenda, cita suas fontes, embora poderia tê-las citado de uma forma mais pontual, formal. Eu mesmo não lotei o texto de notas por dois motivos: primeiro, o editor não queria - $\mathrm{e}$ acho que ele teve razão; segundo, porque sou muito desorganizado, escrevo a história do Brasil pelo método confuso do Mendes Fradique, faço uma bagunça, um caos, não mais sei onde vão os livros que pesquisei. Escrevi esses livros com muita rapidez. Viagem do descobrimento em 44 dias. Náufragos, traficantes e degradados em 62 dias. Capitães do Brasil em 95 dias. E não é escrever. Eu escrevi e editei! Fiz todas aquelas notas laterais, fiz tudo, entrega o livro pronto. Quero ver quem é que lida com esses prazos. Nunca fui treinado para as citações corretas, embora, claro, eu as conheça.

Mas mesmo com essas limitaçóes, o que aconteceu? Mais de dez crianças e adolescentes chegaram e disseram para mim que seriam historiadores por minha causa. Quantos historiadores já ouviram a frase: "Foi o primeiro livro que li na minha vida"? Mais de cinco pessoas me disseram isso. Quantos acadêmicos foram lidos por taxistas, enfermeiras, guardas de trânsito, ascensoristas, carteiros, presidentes e seus motoristas? Eu fui lido pelo presidente Fernando Henrique Cardoso. Em Brasília, quando ele me chamou para um encontro, o chofer dele revelou que o presidente havia falado tanto da coleção Terra Brasilis que ele mesmo se sentiu obrigado a ler, e que havia achado maravilhoso.

Resumo: O que fabrica o jornalista quando escreve sobre história? Eduardo Bueno, repórter e editor gaúcho, ganhou notoriedade no final dos anos 1990 com uma série de livros sobre as primeiras décadas da colonização brasileira. O objetivo confesso de sua narrativa era o de transformar o leitor em "testemunha presencial" dos fatos passados. Mas que passado é esse? Por que é tão popular? No que ele se difere daquele evidenciado, explicado e escrito pelo historiador profissional? A presente entrevista pode oferecer algumas pistas que nos ajudam a entender essas questões.

Palavras-chave: narrativa jornalística da história, comemorações, divulgação científica, mercado editorial, passado como produto.

Journalism and it's account on history: the past as a commodity

Abstract: What's the role of the non-academic historian? Eduardo Bueno, journalist and author, became popular after a series of books on brazilian early colonial history. These works, however, have been received with controverse by professional historians. "To transform the reader into a presencial witness" of the past, so he claimed, would be his major objective. But 
what sort of past would we have here? Why is it so popular? How could it be different from the historian's past? The following interview give us some leads to start understanding these questions.

Keywords: journalistic account on history, commemorations, non-academic historiography, publishing market, past as a commodity.

Recebido em 09/03/2012

Aprovado em 05/04/2012 